\title{
EVIDENCE OF POSTTRAUMATIC COAGULOPATHY IN CASE OF THE SEVERE COMBINED THORACIC TRAUMA
}

\author{
Myroslav Stupnytskyi and Victor Zhukov
}

Biochemistry department, Kharkiv national medical university, Kharkiv, Ukraine

\begin{abstract}
Early coagulopathy associated with trauma - result of exaggerate activity during the initiation phase of coagulation. The aim of this study was to determine the diagnostic value of the coagulopathy markers for metabolic monitoring of the severe combined thoracic trauma and it's possibly to help in outcome prediction. This retrospective study was performed on 73 male polytrauma patients from 20 to 68 years old. The prothrombin time, fibrinogen concentration and $\beta$-Naphthol test were estimated on 1-2-d, 3-4-th and 5-6-th days after trauma. The results suggest that hypocoagulation occurs early in equal extent for survivals and non-survivals. Coagulation abnormalities are the result of vital functions disturbances rather than direct tissue injury. Disseminated intravascular coagulation with a fibrinolytic phenotype is the predominant and initiative pathogenesis of trauma-related coagulopathy with maximal expression on 5-6th day. Appearance of positive $\beta$-Naphthol test on 5-6-th day increases probable mortality from 18.47 $19.37 \%$ to $26.91-28.08 \%$.
\end{abstract}

\section{KEYWORDS}

Severe combined thoracic trauma, Trauma-induced coagulopathy, outcome prediction, Prothrombin time, Fibrinogen, $\beta$-Naphthol test.

\section{INTRODUCTION}

Accidental injury causes over 3 million deaths worldwide annually. It is the second most common reason of lethal outcomes in all age groups and the leading cause of death in adults younger than 45years. Among the causes of deaths due to trauma, motor vehicle crashes accounts for as much as $70 \%$ of deaths [1]. Polytrauma is the complicated process caused by the damage of a few body areas with manifestation of mutual overloading syndrome, which results in deep metabolism violations [2]. Thoracic trauma is one of the leading causes of morbidity and mortality in developing countries [3]. The availability of resuscitative medication and scheduled surgical strategies for management of polytrauma patients led to a better survival. Table 1 presents the summary statistics for mortality rate in case of the combined thoracic trauma taken from several studies.

Trauma scoring systems evolved during the last decades demarcate the threshold of a polytrauma but don't make outcome prediction. Searching of the best marker or set of markers for the accurate diagnosis, exact prognosis and unprejudiced treatment control of patients with polytrauma is on-going. Rapid identification and offensive resuscitation for correction of the diminished metabolic functions improves survival and reduces complications rates in severely injured patients.

Negative outcomes of altered hemostasis are not limited to death from acute haemorrhage. Organ dysfunction and failure are potential results of untreated shock. Coagulation is the part of inflammation pathogenesis and its prevalent activation results in the systemic inflammatory response syndrome with increased susceptibility to sepsis [4]. 
Table 1. Mortality rate in case of combined thoracic trauma.

\begin{tabular}{|c|c|c|c|}
\hline Author & $\begin{array}{l}\text { Number } \\
\text { of } \\
\text { Patients }\end{array}$ & Mortality & Notes \\
\hline $\begin{array}{l}\text { M. Ried, T. Bein, A. Philipp } \\
\text { [et al.] } 2013 \text { [5] }\end{array}$ & 52 & $11(21 \%)$ & $\begin{array}{l}\text { Two technics of } \\
\text { extracorporeal lung support } \\
\text { were compared }\end{array}$ \\
\hline $\begin{array}{l}\text { R. Demirhan, B. Onan, K. Oz } \\
\text { [et al.] } 2009 \text { [3] }\end{array}$ & 2775 & $\begin{array}{c}491 \\
(17.7 \%)\end{array}$ & $\begin{array}{l}\text { Retrospective analysis of 10- } \\
\text { year experience of thoracic } \\
\text { trauma treatment }\end{array}$ \\
\hline $\begin{array}{l}\text { G. Costa, F. Tomassini, S.M. } \\
\text { Tierno [et al.] } 2010 \text { [6] }\end{array}$ & 46 & $\begin{array}{c}17 \\
(36.6 \%)\end{array}$ & $\begin{array}{l}\text { Only thoracoabdominal } \\
\text { trauma patients }\end{array}$ \\
\hline $\begin{array}{l}\text { I.L. Sohaneva, Yu.P. Kostikov, } \\
\text { G.R. Gilborg [et al.] } 2004 \text { [7] }\end{array}$ & 343 & $\begin{array}{c}48 \\
(13.9 \%)\end{array}$ & 15-78 aged patients \\
\hline $\begin{array}{l}\text { Yu.V. Puras, A.E. Talypov } 2013 \\
\text { [8] }\end{array}$ & 304 & $\begin{array}{c}128 \\
(42 \%)\end{array}$ & $\begin{array}{l}\text { Only craniothoracic trauma } \\
\text { patients }\end{array}$ \\
\hline V.D. Sheiko 2001 [9] & 152 & $\begin{array}{c}41 \\
(26.9 \%)\end{array}$ & $\begin{array}{l}\text { Patients with the severe } \\
\text { combined thoracic trauma } \\
\text { and thoracoabdominal } \\
\text { trauma }\end{array}$ \\
\hline $\begin{array}{l}\text { P. Mommsen, C. Zeckey, H. } \\
\text { Andruszkow [et al.] } 2012 \text { [10] }\end{array}$ & 278 & $22(7.9 \%)$ & $\begin{array}{l}\text { Patients with AIS head }>2 \\
\text { were excluded }\end{array}$ \\
\hline V.G. Poltoratsky 2004 [11] & 1065 & $\begin{array}{c}475 \\
(44.6 \%)\end{array}$ & $\begin{array}{l}\text { Patients with thoracic } \\
\text { injuries in consisting of } \\
\text { combined head trauma }\end{array}$ \\
\hline $\begin{array}{l}\text { V.V. Mishchenko, V.V. Grubnik } \\
\text { [et al.] } 2014 \text { [12] }\end{array}$ & 115 & $8(6.9 \%)$ & $\begin{array}{l}\text { Only thoracoabdominal } \\
\text { trauma patients }\end{array}$ \\
\hline $\begin{array}{l}\text { V.T. Veysi, V.S. Nikolaou, C. } \\
\text { Paliobeis [et al.] } 2009 \text { [13] }\end{array}$ & 1164 & $\begin{array}{c}218 \\
(18.7 \%) \\
\end{array}$ & Over 16 years aged patients \\
\hline $\begin{array}{l}\text { E.M. AlEassa, M.J. Al-Marashda, } \\
\text { A. Elsherif [et al.] } 2013 \text { [14] }\end{array}$ & 301 & $23(7.6 \%)$ & 1-90 years aged patients \\
\hline $\begin{array}{l}\text { S. Huber, P. Biberthaler, P. } \\
\text { Delhey [et al.] } 2014 \text { [15] }\end{array}$ & 22462 & $\begin{array}{c}3969 \\
(17.5 \%)\end{array}$ & $\begin{array}{l}\text { Adult patients with blunt } \\
\text { injuries }\end{array}$ \\
\hline $\begin{array}{l}\text { B. Virgós Señor, C. Nebra } \\
\text { Puertas, C. Sánchez Polo [et al.] } \\
2004 \text { [16] }\end{array}$ & 63 & $\begin{array}{c}27 \\
(42.8 \%)\end{array}$ & $\begin{array}{l}\text { Extremity trauma patients } \\
\text { were excluded }\end{array}$ \\
\hline $\begin{array}{l}\text { S. Emircan, H. Ozguc, S.A. Aydin } \\
\text { [et al.] } 2011 \text { [17] }\end{array}$ & 247 & $\begin{array}{c}80 \\
(32.4 \%)\end{array}$ & $\begin{array}{l}\text { Without injuries of large } \\
\text { vessels and oesophagus }\end{array}$ \\
\hline
\end{tabular}

As can be seen from the table 1 average mortality of polytrauma patients with the severe combined thoracic injuries is $18.47-19.37 \%$.

More than $24 \%$ of severely injured patients have signs of acute coagulopathy, that has been shown to be closely associated with more higher mortality (46.0\% vs. 10.9\%) [18]. Early activation and consumption of the coagulation factors with development of a disseminated intravascular coagulopathy (DIC) and secondary hyperfibrinolysis was detectable already at the accident site. Recent data suggest that the early development of trauma-induced intravascular coagulopathy (TIC) mainly differs from the sings of classical DIC. Brohi and colleagues suggests that TIC (reasonably prolonged activated partial thromboplastin time, prothrombin time or international normalized ratio [19], [20]) is the result of the combination of traumatic injury and the severity of shock and by the degree of tissue hypoperfusion [21]. 
TIC is a complex pathophysiologic process, not simplistic explanations which support current clinical practice. Six primary mechanisms involved in the development of TIC: tissue injury, traumatic shock, hypothermia, acidemia, hemodilution and inflammation [22]. Shock is the main etiologic factor of early coagulopathy, but requires initiator - tissue injury [23]. During manifestation of traumatic shock with initiated intravenous therapy, hemodilution provokes the established haemostatic disorder. If the bleeding is not stopped, hypothermia and acidemia intensify started coagulopathy. The clinical importance of inflammation in the development of TIC has not been fully elucidated [19].

Early coagulopathy associated with trauma - result of exaggerate activity during the initiation phase of coagulation. Tissue injury leads to appearance of many sites of endothelial disruption with major releasing of activated coagulation Factors, such as X, II, V, and VIII. Shock slows the clearance of thrombin and increases it's binding to thrombomodulin on neighbour normal endothelial cells resulting to activation of protein $\mathrm{C}$ and inactivation of Va, VIIIa, and PAI-1. This is not DIC as during sepsis and other conditions [24]. It is early developed with prolonged prothrombin and partial thromboplastin times and a relative sparing of platelets and fibrinogen concentration. Although similarities are present, but the initiators, pathophisiologocal mechanisms and treatment strategies are different [19]. The mechanisms of TIC are not well understood yet; the major initiators are hypoperfusion, endothelial injury, and inflammation, with the different types of polytrauma adding deep layers of complexity to its severity, progression, and clinical manifestation.

However, diagnostic value of the coagulopathy markers for triage process and outcome prediction is not investigated at all yet, especially in case of the severe combined thoracic trauma.

\section{AIM}

The aim of this study was to determine the diagnostic value of the coagulopathy markers for metabolic monitoring of the severe combined thoracic trauma and it's possibly to help in outcome prediction.

\section{MATERIALS AND METHODS}

The retrospective study was performed on 73 male patients from 20 to 68 years old. They were treated at the anaesthesiology and intensive care department for patients with combined trauma of Kharkiv city clinical hospital of emergency aid named by prof. O.I. Meshchaninov. Including criteria were: polytrauma with pneumothoraxes, hemothoraxes, lung contusions, heart contusions and multiply $(\geq 3)$ rib fractures. 15 male healthy volunteers at the same age were comprised into control group. Examinations were performed on three periods: 1-2-d day after trauma (10.75-33.5 hours), 3-4-th day (48-75.2 hours) and 5-6-th day (97-122 hours). The cohort was divided into groups according to outcome - survival $(n=42)$ and non-survival $(n=31)$. The table 2 gives some of the main characteristics of the patients' groups. 
Table 2. Patient Characteristics (Median (95\% confidence interval)).

\begin{tabular}{|c|c|c|c|c|}
\hline \multicolumn{2}{|c|}{ Numbor of notionts } & Survivors & Non-survivors & $\mathbf{P}$ \\
\hline \multicolumn{2}{|c|}{ Number of patients } & 42 & 31 & - \\
\hline \multicolumn{2}{|l|}{ Age, years } & $41(38,21-44,89)$ & $42(36,7-46,46)$ & $1^{\mathrm{a}}$ \\
\hline \multicolumn{2}{|l|}{ ISS score } & $24,5(22,73-28,22)$ & $34(30,38-38,53)$ & $0,0006^{\mathrm{a}}$ \\
\hline \multicolumn{2}{|l|}{ RTS score } & $7,84(7,051-7,684)$ & $6,17(5,356-6,464)$ & $<0,0001^{\mathrm{a}}$ \\
\hline \multicolumn{2}{|c|}{ TRISS probability } & $0,964(0,871-0,961)$ & $0,717(0,556-0,766)$ & $<0,0001^{\mathrm{a}}$ \\
\hline \multicolumn{2}{|c|}{ Admission time, hours } & $1(0,854-1,97)$ & $1(0,435-3,297)$ & $0,8434^{\mathrm{a}}$ \\
\hline \multicolumn{2}{|l|}{ Craniothoracic } & 6 & 3 & \\
\hline \multicolumn{2}{|c|}{ Thoracoabdominal } & 3 & 1 & \\
\hline \multicolumn{2}{|l|}{ Thoracoscelethal } & 7 & 1 & \\
\hline \multicolumn{2}{|c|}{ Craniothoracoabdominal } & 5 & 5 & $0,0901^{\mathrm{b}}$ \\
\hline \multicolumn{2}{|c|}{ Craniothoracoscelethal } & 7 & 7 & \\
\hline \multicolumn{2}{|c|}{ Thoracoabdominoscelethal } & 5 & 2 & \\
\hline \multicolumn{2}{|c|}{ Craniothoracoabdominoscelethal } & 9 & 12 & \\
\hline \multirow{3}{*}{ AIS Skin } & 0 & 18 & 15 & \multirow{3}{*}{$0,7837^{\mathrm{b}}$} \\
\hline & 1 & 22 & 14 & \\
\hline & 2 & 2 & 2 & \\
\hline \multirow{6}{*}{ AIS Head } & 0 & 18 & 4 & \multirow{6}{*}{$0,0008^{\mathrm{b}}$} \\
\hline & 1 & 10 & 7 & \\
\hline & 2 & 1 & 1 & \\
\hline & 3 & 9 & 7 & \\
\hline & 4 & 3 & 6 & \\
\hline & 5 & 1 & 6 & \\
\hline \multirow{4}{*}{ AIS Facial } & 0 & 31 & 24 & \multirow{4}{*}{$0,9312^{\mathrm{b}}$} \\
\hline & 1 & 10 & 5 & \\
\hline & 2 & 0 & 1 & \\
\hline & 3 & 1 & 1 & \\
\hline \multirow{2}{*}{ AIS Thorax } & 3 & 12 & 3 & \multirow{2}{*}{$0,0772^{\mathrm{c}}$} \\
\hline & 4 & 30 & 28 & \\
\hline \multirow{5}{*}{ AIS Abdomen } & 0 & 20 & 11 & \multirow{5}{*}{$0,2169^{\mathrm{b}}$} \\
\hline & 1 & 11 & 8 & \\
\hline & 2 & 1 & 2 & \\
\hline & 3 & 6 & 4 & \\
\hline & 4 & 4 & 6 & \\
\hline \multirow{5}{*}{ AIS Extremities } & 0 & 14 & 9 & \multirow{5}{*}{$0,6032^{\mathrm{b}}$} \\
\hline & 1 & 4 & 2 & \\
\hline & 2 & 9 & 7 & \\
\hline & 3 & 13 & 12 & \\
\hline & 4 & 2 & 1 & \\
\hline
\end{tabular}

$\mathrm{a}$ - Mann Whitney, $\mathrm{b}-\chi^{2}$-test for trends, $\mathrm{c}-$ two-sided Fisher`s exact test.

The prothrombin time was estimated by standard Quick's method [25]. The fibrinogen concentration was measured with help of gravimetric Rutberg's method [26]. $\beta$-Naphthol test was used for detection and semiquantitative measure of fibrin-monomers and was interpreted as: "“."negative; "+" - weakly positive; "++" - positive; "+++" - strongly positive [27]. 
Statistical analysis was performed using the GraphPad Prism 5.03. Mann-Whitney test was used to assess differences between two groups. Two-sided Fisher`s exact test and chi-square test for trends were performed to consider differences in nominal data. For investigation the relationship between two variables Spearman correlation coefficient was used. The significance level was specified as $\mathrm{p}<0.05$.

\section{RESULTS AND DISCUSSION}

Acute coagulopathy is present at admission in $25 \%$ of polytrauma patients and is associated with a 4-fold increase in mortality [4]. Coagulation disorders after trauma is complex pathophysiological process that involves all components of the hemostatic cascade. Activation or dysfunction of fibrin generation process or both, platelets, and endothelium cells each play a role, in combination with inhibition of clot formation by anticoagulant and fibrinolytic mechanisms. Which of these mechanisms plays the leading role depends on the kind of tissue injuries and severity of polytrauma, the degree of circulatory physiologic disturbances, and the deleterious side effects of subsequent therapies. Most studies have been aimed to the investigation of coagulation proteases role, which may be lost or inhibited in case of major trauma. Loss may be absolute as the result of widespread activation and consumption, or relative due to hemodilution. Inhibition can be as the result of such factors as hypothermia and acidosis or through the activation of fibrinolysis and anticoagulation. Six key etiologic factors of coagulopathy in trauma patients are distinguish: tissue injury, traumatic shock, hypothermia, acidemia, hemodilution and inflammation.

It can be seen from the table 2, there were no reliable and significant differences in age and the polytrauma types according to anatomical principle of classification between patients groups. Comparison of the coagulation markers in patients' groups and healthy volunteers from the control group is presented in Table 3.

Table 3. The dynamics of the coagulation markers in blood plasma (Mean \pm standart deviation).

\begin{tabular}{|c|c|c|c|c|c|}
\hline & \multirow{2}{*}{ Control } & \multirow[b]{2}{*}{ Group } & \multicolumn{3}{|c|}{ Patients } \\
\hline & & & 1-2-d & 3-4-th & 5-6-th \\
\hline \multirow{2}{*}{$\begin{array}{l}\text { Fibrinogen } \\
\text { concentration, g/L }\end{array}$} & \multirow[b]{2}{*}{$\begin{array}{c}3.044 \pm \\
0.00888\end{array}$} & $\mathbf{S}$ & $\begin{array}{c}2.734 \pm 0.07282 \\
\mathrm{p} 1=0.0165\end{array}$ & $\begin{array}{c}2.698 \pm 0.08081 \\
\mathrm{p} 1=0.0095\end{array}$ & $\begin{array}{c}2.612 \pm 0.05305 \\
\text { p1 }=0.0086\end{array}$ \\
\hline & & NS & $\begin{array}{c}2.572 \pm 0.09766 \\
\text { p1 }=0.0097 \\
\text { p2 }=0.0406\end{array}$ & $\begin{array}{c}2.529 \pm 0.09625 \\
\text { p1 }=0.0023 \\
\text { p2 }=0.1996\end{array}$ & $\begin{array}{c}2.671 \pm 0.1236 \\
\text { p1 }=0.0067 \\
\text { p2 }=0.9535\end{array}$ \\
\hline \multirow{2}{*}{$\begin{array}{l}\text { Prothrombin time, } \\
\text { sec }\end{array}$} & \multirow{2}{*}{$\begin{array}{l}15.07 \pm \\
0.3581\end{array}$} & $\mathbf{S}$ & $\begin{array}{c}16.64 \pm 0.2011 \\
\mathrm{p} 1=0.0007\end{array}$ & $\begin{array}{c}16.26 \pm 0.221 \\
\text { p1 }=0.0135\end{array}$ & $\begin{array}{c}16.6 \pm 0.1706 \\
\mathrm{p} 1=0.0006\end{array}$ \\
\hline & & NS & $\begin{array}{c}16.23 \pm 0.1952 \\
\text { p1 }=0.0099 \\
\text { p2 }=0.1476\end{array}$ & $\begin{array}{c}16.26 \pm 0.1802 \\
\text { p1 }=0.0097 \\
\text { p2 }=0.9322\end{array}$ & $\begin{array}{c}16.71 \pm 0.1969 \\
\text { p1 }=0.0009 \\
\text { p2 }=0.6994\end{array}$ \\
\hline
\end{tabular}

p1 and p2 - according to Mann Whitney test in comparison with control group and survivors, respectively, $\mathrm{S}$ - survivors, NS - non-survivors.

There are significant differences of fibrinogen concentration between the both patients groups and controls through all the investigation period. Common dynamics was observed for both patients groups. Reliable decrease in comparison to control group was found on the 1-2-d day after trauma on $10.18 \%$ in survivors and on $15.51 \%$ in non-survivors that is on $5.93 \%$ less than in survivors group. Further analysis showed that on the 3-4-th day of posttraumatic period the level of 
fibrinogen concentration continue decrease and was on $11.37 \%$ lower for survivors and on $15.6 \%$ lower for non-survivors in comparison to control group. The level of decrease on the 5-6-th day was on $14.19 \%$ lower for survivors and on $12.25 \%$ lower for patients with poor outcome.

The bottom half of the table 3 shows the dynamic of prothrombin time during early posttraumatic period. Significant prolongation of prothrombin time was got for both patients groups in comparison to control though all investigation period. The level of increase was on $10.41 \%$ for the 1-2-d day, on $7.89 \%$ for the 3-4-th day and on $10.15 \%$ for the 5-6-th day after trauma for patients from survivor group. The dynamic of this coagulation marker in patients from nonsurvivors group was different and characterized as increase on $7.69 \%$ for the 1-2-d day, on $7.89 \%$ on the 3-4-th day and on $10.88 \%$ for the 5-6-th day higher than in volunteers. Statistical reliable differences between two groups of patients were not observed during early posttraumatic period up to 5-6-th day.

There were relative correlations between prothrombin time estimated on 1-2-d day after trauma and objective scales that characterise patient's status on admission: RTS scale $-r=0.3395$, $(0.1118-0.5333), p=0.0033$ and TRISS probability $-r=0.376,(0.1529-0.5626), p=0.001$. Less significant correlations were between fibrinogen concentration on 1-2-d day and trauma objective scales: RTS $-\mathrm{r}=0.2866,(0.05352-0.49), \mathrm{p}=0.014$ and TRISS $-\mathrm{r}=0.2868,(0.05383-0.4902)$, $\mathrm{p}=0.0139$. These data supports the theory about role of coagulation cascades in mechanisms of fatal pathogenesis as a part of so called "lethal triad" [28]. During trauma, massive tissue factors exposure results in intensive early, prehospital fibrin clot formation. Such activation of plasmatic coagulation cascade and the further fibrinolysis (thrombin stimulates the release of tissue plasminogen activator) waste and weak haemostatic factors. Factors of coagulation are further affected by fluid dilution proportional to the degree of traumatic shock. Haemostasis is also strongly influenced by the hypothermia. Both platelet function and clotting factors are deteriorated. But, laboratory assays, performed at normal temperature, may undervalue the extent of hemostatic dysfunction [24]. Also, coagulation disturbancec are affected by acidosis, as the result of inadequate tissue oxygenation. Blood $\mathrm{pH}$ should be closely monitored for detection of acidosis and therefore acidotic coagulopathy. Metabolic acidosis reflects low tissue perfusion and degree of traumatic shock, optimized resuscitation is also required. Interestingly, that there was no significant correlation with objective scale that characterise injury severity (ISS), suggests existence of coagulation abnormalities dependence on patient's general status and vital functions disturbances therefore the level of traumatic shock.

Table 4. $\beta$-Naphthol test dynamics in patients groups.

\begin{tabular}{|c|c|c|c|c|c|c|}
\hline Day & \multicolumn{2}{|c|}{ 1-2-d } & \multicolumn{2}{c|}{ 3-4-th } & \multicolumn{2}{c|}{ 5-6-th } \\
\hline Group & S & NS & S & NS & S & NS \\
\hline "__“ & 21 & 9 & 8 & 3 & 8 & 1 \\
\hline "++" & 19 & 17 & 27 & 14 & 31 & 11 \\
\hline "++" & 2 & 5 & 6 & 4 & 3 & 8 \\
\hline "+++" & 0 & 0 & 1 & 2 & 0 & 1 \\
\hline $\mathbf{P}^{\mathbf{1}}$ & \multicolumn{2}{|c|}{0.0324} & \multicolumn{2}{|c|}{0.2368} & \multicolumn{2}{c|}{0.0008} \\
\hline
\end{tabular}

$1-\chi^{2}$-test for trends.

As table 4 shows, there are significant differences in semi quantitative $\beta$-Naphthol test on 1-2-d and 5-6-th days after trauma between two groups of patient, more expressed on 5-6-th day. These data suggests manifestation of fibrinolysis in DIC that occurs at an early phase of trauma more intensive in patients from non-survival group. The measurements of coagulation markers and 
fibrinolysis have demonstrated that DIC at an early phase of trauma (24-48 hours) progresses dependently at a late phase until 5 or 6 days after the trauma [22]. The lowest p-value on 5-6-th day of posttraumatic period supports recent experimental evidences that DIC is the predominant and initiative pathogenesis of TIC and that the acute coagulopathy of traumatic shock and coagulopathy of trauma equal DIC with a fibrinolytic phenotype at an early phase of polytrauma [22].

The lowest $\mathrm{p}$-value for accessing differences between survival and non-survival groups was obtained for $\beta$-Naphthol test on 5-6-th day of posttraumatic period. So the congenital table $2 \times 2$ method was used for evaluation of prognostic ability for outcome prediction in this period. Negative and weakly positive results were united into one group, positive and distinctly positive results were united into second group respectively (Fig. 1).

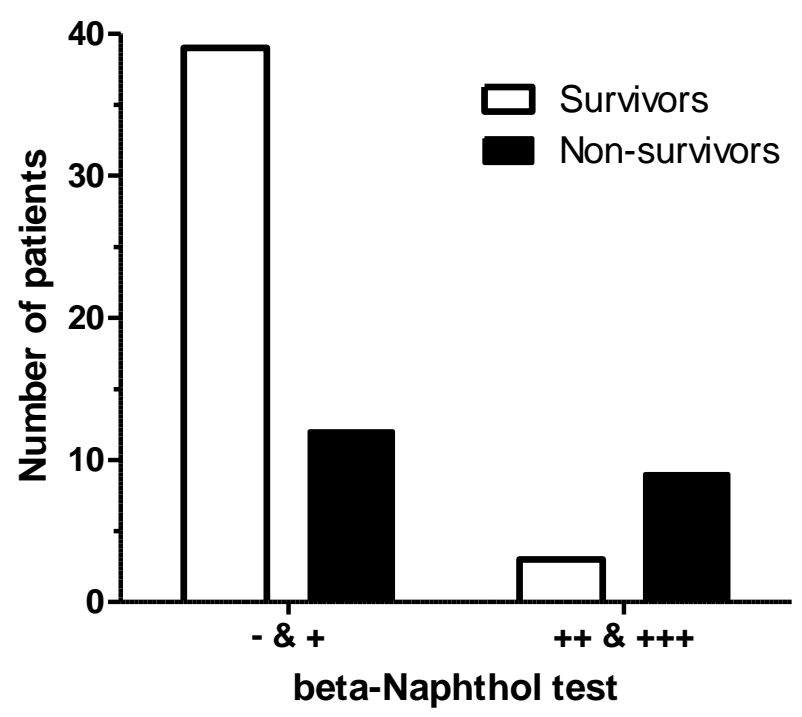

Figure 1. United contingency of $\beta$-Naphthol test results on 5-6-th day after trauma.

Significance analysis of united contingency table 2x2, according to two-sided Fisher's exact test, gives the p-value 0.0014. Analysis for strength of association: relative risk - 3.059 (1.134 $8.248)$, odds ratio - $9.750(2.268-41.92)$. The classification function was evaluated as: sensitivity $-0.9286(0.8052-0.9850)$, specificity $-0.4286(0.2182-0.6598)$, positive predictive value $-0.7647(0.6251-0.8721)$, negative predictive value $-0.75(0.4281-0.9451)$, likelihood ratio -1.625 and accuracy -0.7619 .

According to Byes theorem outcome prediction can be made as follows: if patient with the severe combined thoracic trauma gets positive (++) or strongly positive (+++) $\beta$-Naphthol test on the 56-th day after trauma, the probability of mortality increases from $18.47-19.37 \%$ to $26.91-$ $28.08 \%$.

\section{CONCLUSIONS}

Hypocoagulation occurs early from the 1-2-d day of trauma in equal extent for both groups of patients with the severe combined thoracic trauma. Coagulation abnormalities are the result of vital functions disturbances (the level of traumatic shock) rather than direct mechanical tissue injury. Disseminated intravascular coagulation with a fibrinolytic phenotype at an early phase of trauma is the predominant and initiative pathogenesis of trauma-related coagulopathy with 
maximal expression on 5-6-th day of posttraumatic period. General clotting screening tests, have significant limitations restricting their usefulness in case of polytrauma. Appearance of positive and strongly positive $\beta$-Naphthol test on 5-6-th day after trauma in patient with the severe combined thoracic trauma increases probable mortality from $18.47-19.37 \%$ to $26.91-28.08 \%$.

\section{REFERENCES}

[1] B. Gunetilleke, (2009) "A patient with polytrauma including a severe head injury, haemothorax and cardiac tamponade", Sri Lankan J. Anaesthesiol., vol. 17, no. 2, pp. 80-86.

[2] F. Gebhard and M.S. Huber-Lang, (2008) "Polytrauma - pathophysiology and management principles", Langenbecks Arch Surg, vol. 393, pp. 825-831.

[3] R. Demirhan, B. Onan, K. Oz, and S. Halezeroglu, (2009) "Comprehensive analysis of 4205 patients with chest trauma: a 10-year experience”, Interact. Cardiovasc. Thorac. Surg., vol. 9, no. 3, pp. 450453.

[4] J.R. Hess, K. Brohi, R.P. Dutton, C.J. Hauser, J.B. Holcomb, Y. Kluger, K. Mackway-Jones, M.J. Parr, S.B. Rizoli, T. Yukioka, D.B. Hoyt, and B. Bouillon, ( 2008) "The Coagulopathy of Trauma: A Review of Mechanisms", J. Trauma, Inj. Infect. Crit. Care, vol. 65, no. 4, pp. 748-754.

[5] M. Ried, T. Bein, A. Philipp, T. Müller, B. Graf, C. Schmid, D. Zonies, C. Diez, and H.-S. Hofmann, (2013) "Extracorporeal lung support in trauma patients with severe chest injury and acute lung failure: a 10-year institutional experience", Crit. Care, vol. 17, no. 3, p. R110.

[6] G. Costa, F. Tomassini, S.M. Tierno, L. Venturini, B. Frezza, G. Cancrini, and F. Stella, (2010) "The prognostic significance of thoracic and abdominal trauma in severe trauma patients", Ann. Ital. Chir, vol. 81, pp. 171-176.

[7] I.L. Sohaneva, Yu.P. Kostikov, G.R. Gilborg, A.Yu. Pavlenko, D.V. Safronov, M.E. Vodka, (2004) "The therapeutic and diagnostic tactics in trauma patients with combined thoracic injuries", Emergency medical care. Collection of articles of the Kharkiv city hospital emergency aid, no. 7, pp101-103.

[8] Yu.V. Puras, A.E. Talypov, (2013) "Risk factors of poor outcome of surgical treatment of the acute traumatic brain injury”, Neurosurgery, no. 2, pp. 8-16.

[9] V.D.Sheiko, (2001) "Some indices of hemodynamics at different variants of the severe combined trauma in acute period of traumatic disease", Hospital surgery, no. 4, pp. 34-37.

[10] P. Mommsen, C. Zeckey, H. Andruszkow, J. Weidemann, C. Frömke, P. Puljic, M. Van Griensven, M. Frink, C. Krettek, and F. Hildebrand, (2012) "Comparison of different thoracic trauma scoring systems in regards to prediction of post-traumatic complications and outcome in blunt chest trauma," J. Surg. Res., vol. 176, no. 1, pp. 239-247.

[11] V.G. Poltoratski, (2004) "Clinical and epidemiological features of combined cranio-thoracic injury", The Odessa Medical Journal, no. 4 (48), pp. 63-64.

[12] V.V. Mishchenko, V.V. Grubnik, V.V. Gorychiy, (2014) "Toraco-abdominal trauma in practice of the urgance surgeon", Reports of vinnytsia national medical university, vol. 18, no. 1, P 1, pp. $87-$ 90.

[13] V.T. Veysi, V.S. Nikolaou, C. Paliobeis, N. Efstathopoulos, and P.V. Giannoudis, (2009) "Prevalence of chest trauma, associated injuries and mortality: A level I trauma centre experience", Int. Orthop., vol. 33, no. 5, pp. 1425-1433.

[14] E.M. AlEassa, M.J. Al-Marashda, A. Elsherif, H.O. Eid, and F.M. Abu-Zidan, (2013) "Factors affecting mortality of hospitalized chest trauma patients in United Arab Emirates", J. Cardiothorac. Surg., vol. 8, no. 1, p. 57.

[15] S. Huber, P. Biberthaler, P. Delhey, H. Trentzsch, H. Winter, M. van Griensven, R. Lefering, and S. Huber-Wagner, (2014) "Predictors of poor outcomes after significant chest trauma in multiply injured patients: a retrospective analysis from the German Trauma Registry (Trauma Register DGU®)", Scand. J. Trauma. Resusc. Emerg. Med., vol. 22, no. 1, p. 52.

[16] B. Virgós Señor, A.C. Nebra Puertas, C. Sánchez Polo, A. Broto Civera, and M.A. Suárez Pinilla, (2004) "Predictors of outcome in blunt chest trauma", Arch. Bronconeumol., vol. 40, no. 11, pp. 489-494. 
[17] S. Emircan, H. Ozguc, S.A. Aydin, F. Ozdemir, O. Koksal, and M. Bulut, (2011) "Factors affecting mortality in patients with thorax trauma", Turkish J. Trauma Emerg. Surg., vol. 17, no. 4, pp. 329333.

[18] K. Brohi, J. Singh, M. Heron, and T. Coats, (2003) “Acute traumatic coagulopathy”, J. Trauma, vol. 54, no. 6, pp. 1127-1130.

[19] D. Frith and K. Brohi, (2010) "The acute coagulopathy of trauma shock: Clinical relevance", Surgeon, vol. 8, no. 3, pp. 159-163.

[20] K. Brohi, M. J. Cohen, and R.A. Davenport, (2007) "Acute coagulopathy of trauma: mechanism, identification and effect", Curr. Opin. Crit. Care, vol. 13, no. 6, pp. 680-685.

[21] K. Brohi, M.J. Cohen, M.T. Ganter, M.J. Schultz, M. Levi, R.C. Mackersie, and J.-F. Pittet, (2008) "Acute coagulopathy of trauma: hypoperfusion induces systemic anticoagulation and hyperfibrinolysis", J. Trauma, vol. 64, no. 5, pp. 1211-1217.

[22] M. Hayakawa, A. Sawamura, S. Gando, and N. Kubota, (2011) "Disseminated intravascular coagulation at an early phase of trauma is associated with consumption coagulopathy and excessive fibrinolysis both by plasmin and neutrophil elastase", Surgery, vol. 149, no. 2, pp. 221-230.

[23] R.M. Hardaway, (2003) "A Brief Review of Traumatic Shock Leading to a New Theory and a New Treatment”, J. Appl. Res., vol. 3, no. 4, pp. 464-469.

[24] M. Keel and O. Trentz, (2005) "Pathophysiology of polytrauma”, Injury, vol. 36, no. 6, pp. 691-709.

[25] V.V. Menhsikov, L.N. Delektorskaya, R.P. Zolotnickaya, V.A. Makarov, Yu.I. Tkach, (1987) Laboratory Methods in the clinic: a guide, "Medicine" Moscow.

[26] V.S. Kamyshnikov, (2009) Handbook of clinical and biochemical studies, and laboratory diagnosis, "MEDpress-inform" Moscow.

[27] H. Cummine and R.N. Lyons, (1948) "A study in intravascular thrombosis with some new conceptions of the mechanism of coagulation", Br. J. Surg., vol. 35, no. 140, pp. 337-363.

[28] R. Rossaint, V. Cerny, T.J. Coats, J. Duranteau, E. Fernandez-Mondejar, G. Gordini, P.F. Stahel, B.J. Hunt, E. Neugebauer, and D.R. Spahn, (2006) "Key issues in advanced bleeding care in trauma”, Shock, vol. 26, no. 4, pp. 322-331. 